\title{
The Spirituality of Indang Tigo Sandiang Performance and Godliness in the Pariaman Community of Minangkabau
}

\author{
Surherni, Adriana Gusti Hasnah SY \\ Lecturer in Dance Department, Performing Arts Faculty, Indonesia Institute of the Arts (ISI) Padangpanjang, \\ West Sumatera, Indonesia
}

\begin{abstract}
This study aims to reveal the spirituality of Indang Tigo Sandiang performance and godliness in the Pariaman community of Minangkabau. Spirituality is living with an awareness that God is always close to us, and it is this awareness that cultivates the impulse for human action. Indang Tigo Sandiang (three sides) is a performing art concept in the art of "Indang" that represents the education system of the surau or langgar, a religious center used for worship and education in Minangkabau which is based on tasawwuf or Sufi teachings. Tigo sandiang here refers to the formulation of a performance that originates from three different surau styles or Indang groups that exist in the Pariaman community and are known as guguih (group). These guguih are: (1) Guguih Kulipah (Khalifah) Husein; (2) Guguih Kulipah (Khalifah) Mak Amuik; and (3) Guguih Kulipah (Khalifah) Tan Karim.All three guguihare known for their predominance of tasawwuf teachings - spirituality; such as knowledge of the body, the ma'ani attributes and the 20 attributes of God. These tasawwuf teachings are mystified in the number 7, with 7 anak indang or indang players; the length of performance lasting 14 nights (2 $\mathrm{x} 7$ ); and the number of participants being in multiples of 7, up to 21 groups of anak indang.
\end{abstract}

Keywords: Spirituality, Indang Tigo Sandiang, Godliness, Pariaman

DOI: $10.7176 / \mathrm{ADS} / 83-09$

Publication date:July $31^{\text {st }} 2020$

\section{INTRODUCTION}

Indang is a type of musical instrument classed as a membranophone - a kind of tambourine, also known as rebana, or in the Pariaman community as rapa'i. Tigo sandiang (three sides) refers to the formulation of a performance which originates from three indang styles or groups that exist in Pariaman - known as guguih (group). These guguih are: (1) Guguih Kulipah (Khalifah) Husein; (2) Guguih Kulipah (Khalifah) Mak Amuik; and (3) Guguih Kulipah (Khalifah) Tan Karim. Each of the three guguih has its own special strengths and features in terms of its religious concepts; all are a representation of the education system of the surau (prayer house or religious center used for worship and education). In sociological and religious terms, these guguih are involved in a conditioned psychological conflict; it is impossible for the three of them to unite - they exist in three different conceptions. Philosophically, the ideology of the education system of the surau cultivated the spirituality that gave rise to the concept of Indang Tigo Sandiang in the Pariaman community. As an art text - a performance - it consists of three dimensions, namely literature, music, and "dance". The education system of the surau is characterized by its specialization in the knowledge of Islam, especially Sufi teachings - kaji tarekat. In a performing art context, Indang Tigo Sandiangis an arena for testing the verbal art skills of different Indang groups. Indang Tigo Sandiang texts are full of satire, analogies, allusions, allegories, metaphors, aphorisms, music, and "dance".

Andar Indra Sastra explains that guguih is a form of spiritual bond or brotherhood in which there is a fraternal bond between the different Indang groups in exactly the same way as the concept of spiritual genealogy - ranji in the organizational structure of the Syattariah Tarekat community. This spiritual genealogy of the tarekat is always connected even when the sheikh (teacher) of the tarekatestablishes a surau or place of worship far from the main center. This kind of spiritual genealogy plays an important role in tasawwuf teachings, which teach that an individual's connection with Allah must be through the intermediation of a tasawwuf teacher (tarekat) or sheikh. According to the beliefs and convictions of the followers of tarekat teachings, the teacher serves as an intermediary or door of tawajjuh, and for this reason, the status of the teacher in exercising the tasawwuf teachings is very highly regarded. It is therefore not surprising that in every tarekat center, the picture of the teacher (sheikh) is always on display in a place where it can be seen by members of the tarekat(Sastra: 2016:13).

The names assigned to the guguih are closely related to their particular focus of study. Guguih Kulipah Husein focuses on the Prophet and Disciples,Guguih Kulipah Mak Amuik on the religious leaders who developed and propagated Islam, andGuguih Kulipah Tan Karim on natural phenomena. Indang activities were originally a representation of the education system of the surau, which in Minangkabau is based on tasawwuf or Sufi teachings, and took the form of singing together and playing the rapa ' $i$ as accompanying music. The themes of the texts sung were praises to God, the 20 attributes of God, stories of the Prophet and Apostles, and lessons about Islam. These activities were led directly by the teachers who asked questions related to the religion lessons taught.

It should be understood that followers of the Syatariah Tarekat not only regard Indang Tigo Sandiang as a religious ritual but at certain times as an instrument for accompanying dance - dance that emerges while the 
performers sing. The literary texts are presented in the form of poetry, verse (pantun), and lyrical prose, in a style of cynicism and sarcasm (Asril, 2017). Indang Tigo Sandiang can be classified as religious singing which in practice is interwoven with values of Islamic spirituality.

\section{Literature Study}

Andar (2016) describes the principle of guguih as a form of spiritual bond - brotherhood - in an indang group, which is identical to the concept of spiritual genealogy - ranji - in the organization of a tarekat community. Another article by Andar (2018) discusses the "conflict of two ideologies" in the performance of Salawaik Dulang which is packaged in the form of an art performance. Meanwhile, Suherni et al. (2018) offer an explanation about the concept of Indang Tigo Sandiang, not only in its understanding as a type of musical instrument or membranophone - specifically a single-headed drum, but also in terms of its function as a dance medium or property. The art of dance emerges as the players sing, while the texts are realized in the form of poetry, verse (pantun), and lyrical prose using a language style of cynicism and sarcasm. In an article from 2019, entitled "Indang Tigo Sandiang: The Hybridization of a Popular Image Packagedas a Performing Art in West Sumatera", Suherni et al. discuss Indang Tigo Sandiang not only as a form of entertainment for the local community but also as a popular media and even as a highly profitable economic source. On the concept of spirituality, Hossein Nasr (1993) states that Islamic art is closely related to the element of religious awareness. Meanwhile, Dadang Kahmad and Mansurdin in (2002) both write about the etymology or the origin of the word tarekat. Oman Faturahman (2008) states that in principle there are four types or levels of knowledge: syariat, tarekat, hakikat, andmak'rifat. In another work, AlHabib Usman bin Abdullah bin Yahya (1996) discusses the concept of seven ma'ani attributes, or the comparison of 7 attributes of God with 7 attributes of humans.

\section{Research Method}

This research uses a qualitative descriptive method to explain the problems surrounding the object of the research, supported by relevant literature. The field data was collected through a technique of observation. The data from the observation was used as the basis for further investigation and in-depth examination, followed by interviewing and audio visual documentation for the purpose of the data analysis. The data analysis focuses on the spirituality of Indang Tigo Sandiang and godliness in the Pariaman community of Minangkabau. The aspects treated as the main focus of the research in this article are related to the concept of spirituality in Islam which is closely tied to the element of religious awareness; the spiritual dimension contained therein is connected to Islamic spirituality.

\section{RESULT AND DISCUSSION}

\section{Islamic Spirituality in Indang Performance}

According to Hossein Nasr,art - spirituality - in Islam is closely tied to the element of religious awareness, in which there is an inner dimension that should also be connected to Islamic spirituality. The two primary sources of spirituality in Islam are the Al Qur'an and the substance of the soul of the Prophet Muhammad which continues to be present in a supernatural manner in the world of Islam (Nasr, 1993: 8). In this connection lies the point of contact between the study on the spiritual dimension in the performance of Indang Tigo Sandiangand the views of Hossein Nasr.

Followers of the Syattariah Tarekat use the laws of the Al Qur'an to legalize the execution of religious art activities. Reading stories about the Prophet from the book Majmu'atul Mawaalid in the form of song - including the 20 attributes and the ma'ani attributes, which are the material used in indang performances - serves as a way of deepening their love for Almighty God.

The word tarekat indicates the particular school of thought of tasawwuf or Sufism. Bruinessen (Kahmad,2002:14) writes that: "Followers of tasawwuf usually form a particular order, known as a tarekat. In Indonesia there are three large, popular tarekat: Naqsabandiyah, Syattariyah, and Qadariyah.” The understanding of tarekat in this first context is that "in a literal sense, tarekat (thariqah) means "way", or in this case the way for its followers to grow closer to, or even become one with God" (Kahmad, 2002: 14).

The word tarekatalso indicates the levels of performing good deeds or charity, or the method used for establishing an act of worship (sharia). The connection between sharia and tarekatin this context can be understood from the explanation of Fathurahman (Mansurdin, 2002:30), who writes as follows:

Etymologically, the word 'tarekat' originates from the word tariqah (Arabic) which means the way or instructions for performing an act of worship such as exemplified and established by the Prophet Muhammad. These instructions were followed by the Companions of the Prophet, the Tabi-i'n, and developed from generation to generation ... In their ritual journey, the people of a tarekat make sharia and tarekat a single inseparable entity. This is because sharia contains rules and laws, while tarekat is a way for executing or implementing these rules of law. The tarekat is a spiritual path leading to truth, so the members of the tarekat (salik) always need the guidance of their teachers (mursyid, tuangku, pir, syaikh). 
This explanation by Fathurahman is in line with the position of spirituality according to the opinion of 'Atha'illah \& Anshari (2006:vi), both in its connection with sharia, and thariqah as an aspiration of Sufism. It is explained that sharia, the main pathway from God's word, is an important foundation for thariqah, a small path which branches off the main pathway and guides a person on his or her spiritual journey to become aware of experiencing God's presence in this life, not only on the Day of Reckoning. In this case, the principle of tarekat is encompassed by four kinds or levels of knowledge, such as those of the Syattariah Tarekat, as follows:

(1) syariat (sharia) means obeying all the regulations that have been outlined in Islam; (2) tarekat is defined by Aboebakar Atjeh as a path, way, or instructions in worship, while Hamka states that between the creator of the universe and other beings there is a life "journey" that must be undertaken; (3) hakikat is the absolute truth that comes only from God; (4) mak'rifat is explained by Hamka as the end of a journey of knowledge, feelings, experience, charity, and worship (Mansurdin,2002:6).

Islamic spirituality in the performance of indangis contained in the material of the 20 attributes, the ma'ani attributes, knowledge of the body, and so on. The source of this material becomes a spiritual medium for followers of the Syattariah Tarekat to improve the quality of their godliness. This quality of godliness is sung about in rhythmic patterns in the performance of indang - part of the tarekatteachings.

On the subject of tarekat, teachers usually begin by teaching about the basic way of the tarekat: the 20 attributes of God, lessons about the body, about extinguishing oneself before death, and so on. In connection with the way of tarekat, Omar Faturahman explains:

"The way of tarekatinvolves two actions: first, tanazzaul (tanzawul), which means descending, and second, taraqqi (taruka), which means ascending. Beginning withtanazzaul, a descent is made to discover the characteristics of holiness (jalal) and beauty (jamal) and from that ... light will emerge from the essence of Allah. The light becomes Muhammad, from Muhammad, from Muhammad emerges the light, and the light becomes Muhammad, from Muhammad emerges the light, and the light becomes sa'yansabitah, from a'yansabitah emerges the light, the light becomes fire, the light of the fire becomes passion, from the fire emerges the wind, from the wind emerges the water, from the water emerges the earth (Faturahman, 2008: 171).

In principle, the way of tarekat described by Oman Faturahaman above explains how Allah created; through the word kun (came into being) emerged the word nur (light), which then became Muhammad. From the light of Muhammad came fire, wind, and water. This way of teaching tarekatis used as material in the education system of the surau in Pariaman, Minangkabau, including teaching about the 20 attributes or characteristics of Allah, which must be recognized.The twenty attributes are: (1) wujud (existence); (2) qidam (first/original); (3) baqa (infinite); (4) mukhalfatulilhawadis (different from all the creatures He created); (5) qiyamuhu binafsihi (Allah stands alone); (6) wahdaniyah (singular/one); (7) qudrat (powerful); (8) iradat (having intention) (9) ilmun (knowing) (10) hayat (alive); (11) sam'un (hearing); (12) basar (seeing); (13) kalam (speaking); (14) qadirun (exalted) (15) muridun (having a will); (16) 'alimun (all-knowing) (17) hayyun (living); (18) sami'un (all-hearing); (19) basyiran (all-seeing) (20) mutakalimun (all-speaking). In order to memorize these characteristics, they are usually sung to a certain rhythm (Andar, 2016: 4).

From the lesson about the twenty attributes or characteristics of Allah, it can be seen that there are 7 (seven) attributes of Allah that are similar to attributes of humans - known as thema'aniattributes. Habibusman Bin Yahya states that the form of the lessons related to tasawwuf is designed to study these twenty attributes. One of the points that is associated with the method of 7 (seven) is the ma'aniattributes, or the attributes of God that are also possessed by human beings, namely: (1) sami'un (listening); (2) basyirun (seeing); (3) qudrat (powerful); (4) iradat (having intention); (5) 'alimun (knowing); (6) hayat (living); and (7) kalam (speaking) (Yahya, 1996: 1222). The comparison of these 7 (seven) attributes of God with the 7 (seven) attributes of the human beings He created gives rise to a concept known asinsanul kamil (a perfect human being) manifested with the character of God - Al-insanul-illahi - which is the central theme in lessons of tarekat; godliness that is represented in the performance of indang tigo sandiang in the Pariaman community in West Sumatra.

\section{Performance of Indang Tigo Sandiang and Godliness}

The growth of groups in each surau provided new inspiration for teachers from the different surau to visit each other in a gesture of friendship (silaturahmi). Asril writes that this silaturahmi between different surau was further established by holding indang contests. In these contests, each indang group asked and answered questions about the 20 attributes of God, the history of the Prophet and Apostles, and general knowledge about Islam (Asril, interview, 2017). The skills and experience asking and answering questionsthat had already been practiced between the teachers and their students was displayed during these visits in front of other groups, or guguih, in an indang performance. Each indang group was led by a teacher who acted as the leader of the group (tuo indang). Batandang using the art of indangwas also often referred to as manapa (going to visit); in this context manapa and batandanghave the same meaning.

The goal of batandang was essentially to test the religious knowledge of each student in the surau represented, 
or how well the students had mastered their knowledge of religion from the lessons taught. In this context, there was also the hidden intention of testing the skills or ability of the teachers in their knowledge of Islam - knowledge of tarekat. The purpose of these tests was to examine or question the competence of teachers in the surau (Asril, 2017).

The complexity of Indang as a product of behaviour is related to the norms and values upheld by the Pariaman community. These norms and values were formed based on religious principles or belief in the methods of tasawwuf. Aesthetically, the representation of these methods of tasawwuf can be identified at least in the three main components of Indang: (1) anak indang (the indang players); (2) tukang dikiaorkulipah (the dhikr performer orcaliph); and (3) the management of the performance.

\section{Anak Indang}

There are at least 7 (seven) anak indang, or indang players; one of these is the central figure, known as the tukang aliah (tukang alih). The 6 (six) players to the right and left of the tukang aliahhave the roles of tukang apik (tukang apit), tukang pangga (tukang penggal), andtukang palang (tukang palang). Each of the roles besides the tukang aliah is represented by two players, making a total of 7 (seven) players; the number of tukangpalang can be increased to make a total of around 21 players (see the diagram below).

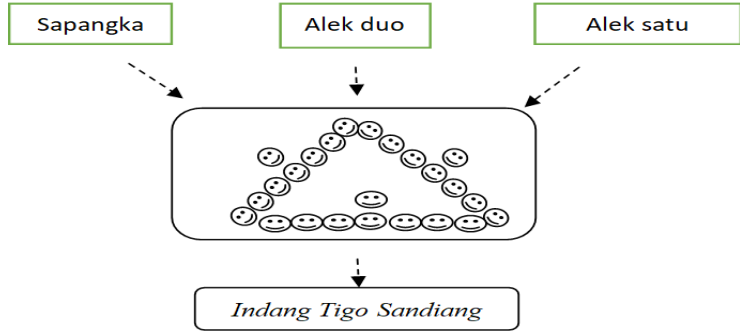

\section{Diagram 1.}

Facing direction and seating position of anak indang

(Asril; perfected by Andar 2017)

The diagram above shows that the anak indang consist of 7 (players), with a single player in the position of tukang aliah. Ediwar explains that the tukang aliah is also known as the tukang karang, and he serves as the main assistant of the tukang dikia in creating the story. In addition, his role is to begin and end the performance, to set the rhythmic patterns of the rapa' $i$ and dance movements, and to guide the transition from one melody to the next. The tukang aliah sits in the center of the anak indang (Ediwar, 1999: 88). The position of the tukang aliah in an indang performance can be compared to that of an imam or teacher who leads the worship or lessons in the tarekat. The seven anak indang are synchronous with the ma'ani attributes, or the comparison of the seven attributes of God with seven attributes of human beings - as well as with the religious doctrine known as martabat nan tujuh. In this sense, it can be said that art in various forms must be synchronous with the life values that prevail in a community.

There are two tukang apik who sit on either side of the tukang aliah in an indang performance. One of them has the role of providing variations (meningkah) to the sound of the rapa'iplayed by thetukang aliah. The other plays different patterns on the rapa 'ito the first tukang apik. There are two tukang panggawho sit to the right and left of the tukang apik. Their role is to follow the rhythmic patterns of the rapa'i played by the second tukang apik. There are also two tukang palang who sit at either end of the group, to the right and left of the tukang pangga. They play the same rhythmic patterns as the second tukang apik.

\section{Tukang Dikia}

The tukang dikiaplays the central role in an indang performance. He sits behind the tukang aliah and is the solo vocalist who presents the text (rundingan); in the second verse of the text, the tukang dikia is joined by the anak indang. In the past, the tukang dikia sung texts about the twenty attributes and the life of the Prophet Muhammad. Teachings about the twenty attributes are usually held in the surau or prayer houses of the Syattariah community.

In Pariaman, indang performances are held in a number of different forms, often in traditional celebrations (alek nagari), either on a small scale (alek ketek) or a large scale (alek gadang). Asril write that alek ketek is the performance of three (3) times naiak indang This is equivalent to 6 (six) performances in which 9 (nine) indang groups take part (Asril, interview, 2017).

An alek gadangevent takes place over a period of two weeks, or 14 days, with 7 (seven) times naiak indang. Thus, the number of indang groups that participate is 21 ( $7 \times 3$ groups). These 21 indang groups are divided into 3 groups with 7 (seven) groups acting as the host or sapangka (the groups hosting the event); 7 (seven) groups acting as the alek duo (consisting of close guests); and 7 (seven) groups acting as the alek satu (consisting of more distant guests) (Ediwar, 1999: 181). In the ontological dimension, this kind of form of performance is based on tasawwuf teachings. This is confirmed by Asril, an expert in the art of indang, who explains that an indang group 
consists of 7 (seven) players, a large scale performance includes 21 indang groups - which is the same as $7 \times 3$, who perform for 14 nights - which is the same as $7 \times 2$, based on the source of tasawwuf teachings (Asril, interview, 2017).

Careful calculations must be made when preparing to organize an indang performance, for the indang sapangka, alek duo, andalek satu. The sapangkais the indanggroup that originates from the village - nagari - where the indang performance is taking place. In the context of an indang performance, in an alek ketek, or small scale celebration, there is only a single sapangka group, while in an alek gadang, or large scale performance, 6 (six) additional groups are needed to act as sapangka (host groups).

These six additional groups come from other nagari and have a close spiritual tie with the first sapangka (organizing group). This close relationship is described as belonging to a single guguih. If indang groups belong to the same guguih it means that they come from the same spiritual background, or school of thought, even though they are from a different nagari. In administrative terms, a nagari is the smallest governmental unit in West Sumatra, which in other areas is usually referred to as a village. At the present time, there are 3 (three) guguih indangin the Pariaman community: (1) Guguih Tankarin;(2) Guguih Amir Unggun; and (3) Guguih Maruik. The word following the word guguih is the name of the teacher who is revered and followed by each group. Therefore, it may be said that even though an indang group comes from a different village, it can still act as a sapangka on condition that it belongs to the same guguih (saguguih) as the hosting group. In relation to this, Ediwar writes as follows:

...an indang group in another nagari can become a sapangka. This group may not be chosen at random but must have a spiritual connection with the sapangkagroup (hosting group), known as guguih...Indanggroups that belong to the same guguih (saguguih) have a strong emotional bond, even though they may come from nagari that are far from one another (Ediwar, 1999: 182).

Indang groups that belong to the same guguih have a strong sense of brotherhood, or strong ties, which matches the concept of the spiritual genealogy of the Syattariah Tarekat. The spiritual ties of a tarekat are always connected when the sheikh (teacher of the tarekat) builds a surau or prayer center far from the main center.

This kind of spiritual genealogy is of great importance in tasawwuf teachings - in relation to connecting with Allah - godliness. In order to connect with Allah, an intermediary is needed, which in this case is the tasawwuf teacher (tarekat) or sheikh. The followers of a tarekatbelieve that they must pass through the door of tawajjuh, by means of the intermediation of a teacher. In other words, the position of a teacher in exercising the tasawwuf teachings is very highly regarded. It is not surprising that wherever a tarekat center is built, the picture of the teacher (sheikh) is always put on display in a place where it can be seen by members of the tarekat.

In tasawwuf teachings, godliness is encouraged through a passion for spirituality by means of the medium of dhikr and art - including barzanji. Hajizar explains that the aura of barzanji singing stimulates the spirituality inside a person to move closer towards Almighty God, because this singing provokes an energy of Islamic spirituality to strive for truth in the highest form. Thus, the achievement of a spiritual dimension through the practice of barzanji becomes one with the beauty of the barzanji singing itself (2017: 175). This domain of godliness is not only achieved through reciting the book of Barazanji but can also be achieved through the performance of Indang Tigo Sandiang which promotes the teachings of tarekat, namely the ma'ani attributes, the 20 attributes, and knowledge about the body, sung together by the indang group.

The spiritual life of followers of the Syattariah Tarekat is applied in various Islamic ritual ceremonies, both connected to the basic principles or mandatory laws of Islam, such as syahadatain (syahadat), reciting the two sentences of syahadat, the pillars of faith, and principles of Islam, or in the form of additional non-mandatory worship or Sunnah laws, such as sunnah prayers, ritual prayers, and making pilgrimages to certain locations associated with pioneers or sheikhs of the Syattariah Tarekat. Followers of the Syattariah Tarekat are quite diligent in developing their Islamic spirituality through tarekat teachings such as tawajjuh, teachings about the attributes, teachings about the pillars or laws of their faith, knowledge about the body, and mysticism (Hajizar, 2017:2). In connection with this, Fadil Munawar in Surherni writes as follows:

... that literary works on religion with a Sufi model usually describe the spiritual and religious experiences of a person with the goal of sharing experiences to benefit others. This Sufi literature is influenced and inspired by, and filled with the spirit of tasawwuf teachings. Sufi literature is literature that reminds people about the greatness of Allah and to follow His commands (Surherni: 2017:316).

In order to gain a deeper knowledge of Islam, perfect execution is needed. Tasawwuf teachings are executed by implementing tarekat. Tarekat appeared as a response to the general need for a closer connection to God. Followers of tarekat are known as Sufis, and they study and follow the tariqah laid out by a teacher or sheikh - as practiced by the tarekat community in the surau. They utter the name of God by singing together and swaying in time to the rhythms of music.

It appears that the art of indang that developed in the Pariaman area is connected with the arrival of Islam, which was brought to the region by religious leaders - mubalig - according to the version of the tarekat of this area. 
As Ediwar explains, the art of indang was originally brought by Islamic leaders from Aceh to Pariaman, and subsequently underwent a process of acculturation with Minangkabau culture. Indang is one of the ways used by Sheikh Burhanuddin to carry out his mission of proselytizing and developing the Islamic religion. The material presented was the 20 attributes of God, which everyone should know: wujud, qidam, baqa, mukhalafatul lilhawadis, qiamuhu binafsihi, wahdaniyah, qudrat, iradat, ilmu hayat samaun, basyar, kalam, qadirun, muridun, alimun, haiyyun, samiun, basyirun, mutakallimun, as well as the story of the prophets and the story of the sheiks. This religious singing was performed while dancing to the accompaniment of music played on tambourines (1999: 76-77). The singing was supported by three main components: music, dance, and recitation. Technically, the anak indang sang poetic texts while moving their bodies and playing the rapa' $i$.

Furthermore, it is known that the religious education system at that time was called halaqah, a system in which students sat in a semicircle facing the teacher. The teacher sang the religion lesson over and over again while moving left and the right, forwards and backwards, to create an atmosphere of devotion which sometimes even led into a trance. This condition cannot be separated from the religious understanding or school of thought of the followers of the Syattariah Tarekat teachings, namely wahdatul wujud, or the way of looking at nature and its Creator as a single entity. In order to achieve this unity with the Creatorin religious activities, a method of levels is implemented known as ilmu martabat nan tujuah (seven phases to achieve the absolute).

It is interesting that the concept of the Indang performance in Pariaman is related to various rules that use the symbol or number seven, such as the number of players - seven, the number of nights in an event - 14 nights $(2 \times 7$ $=14)$, and the 21 (3×7) indang groups that participate in the event - known in Pariaman as tujuah kali naiak anak indang. These conditions are closed tied to the life philosophy of the community which is strongly influenced by concepts of tarekat teachings, in particular the Syattariah Tarekat. The number seven in the teachings of the Syattariah Tarekat is a prominent part of the religious teachings, such as in the teachings about the $m a$ 'ani attributes, or the seven attributes of God that are also present in human beings. There is also a belief amongst followers of the Syattariah Tarekat that a person's death is commemorated after three days (manigo hari), seven days (manujuah hari), and two times seven days (manduo kali tujuah), or 14 days after the death. Other concepts related to the number seven include the use of water from seven mosques (aia tujuah musajik), and sand from seven estuaries (kasiak tujuah muaro) in the practice of "shamanism".

\section{CONCLUSION}

Spirituality in Islam is closely related to the element of religious awareness, and the spiritual dimension contained therein must be connected to Islamic spirituality. In this connection lies the point of contact of the study of spiritual dimension in the performance of Indang Tigo Sandiang in the Pariaman community, which in religious terms is influenced by the teachings of tasawwuf. Indang Tigo Sandiang is a representation of the education system of the surau which is based on the study of tarekat - godliness. This study of tarekat - godliness - includes the 20 characteristics, or the 20 attributes of God that everyone must know. Among these 20 attributes there are 7 attributes of God known as ma'ani attributes which can be compared to 7 attributes found in human beings. These $m a$ 'ani attributes are represented in the performance of indang tigo sandiang.

\section{References}

Asril, 1997. "Seni Pertunjukan Indang Pariaman Minangkabau, Pergeseran dari Religus ke Profan”, Jurnal Seni Budaya ASKI Padangpanjang. Volume 1. Number 1, Year 1, 11 March 1997.

Asril, 2017. Speech presented at the Inauguration Ceremony of the Rector of ISI Padangpanjang at Gedung Huriah Adam ISI Padangpanjang tanggal 12.

Atha'illah \& Khwaja. 2006. Menggapai Keintiman Spiritual Dengan Allah (Al-Hikam Wa Al-Munajat). Translator: Wahyudi Surabaya: Bina Ilmu.

Ediwar, 1999 "Perjalanan Indang dari Surau ke Seni Pertunjukan Rakyat Minangkabaudi Padang Pariaman Sumatera Barat: Postgraduate Master's Thesis, UGM Yogyakarta.

Faturahman, Oman, 2008. Tarekat Syattariyah Di Minangkabau: Teks dan Konteks. Jakarta: Prenada Media Gruup. Hajizar, 2017 Dimensi Spritual Nyanyian Religius Barzanji Masyarakat Nagari Bungo Tanjung Padangpanjang.

Kahmad, Dadang. 2002. Tarekat dalam Masyarakat Islam: Spiritualitas Masyarakat Modern. Bandung: Pustaka Setia.

Mansurdin. 2002. "Dikie Mauluik: Pertunjukan Ritual Keagamaan Masyarakat Ulakan Pariaman Sumatera Barat." Master's Thesis, Yogyakarta: Gajah Mada.

Nasr, Sayyed Hossein. 1993. Spiritualitas dan Seni Islam. Translator: Sutejo. Bandung: Mizan.

Sastra, Andar Indra 2016 "Dimensi Tasauf Dan Konsep Estetika Seni Pertunjukan Indang Pariaman Minangkabau: International Seminar at Intitut Seni Indonesia Padangpanjang, 15 December2016 in Ruang Rektorat Lantai 111 ISI Padangpanjang.

2018. "Sprituality in The Battleof Two Ideologies in The Performance of Salawaik Dulang in Minangkabau". Arts and Design Studies, ISSN 2224-6061 (Paper) ISSN 2225 059x (online) Volume 67 
2018.

Surherni, et.all, (2018) "Indang Tigo Sandiang : A. Representation of The Education System of The Surau Packaged in The Form of a Performing Art in Padang Pariaman, West Sumatera, Indonesia." Arts and Design Studies. ISSN 2224-6061 (Paper) ISSN 2225 059x9online). DOI 10.7176/ADS.Volume 62. 2018

, (2019). " Indang Tigo Sandiang: The Hybridization of a Popular Image Packagedas a Performing Art in West Sumatera", Arts and Design Studies ISSN 2224-6061 (Paper) ISSN 2225 059x9online). DOI 10.7176/ADS.Volume 732019.

Yahya, Al-Habib Usman bin Abdullah bin, (1996). Awaludin Sifat Duapuluh. Jakarta: S.A. Alaydrus. 